\title{
THE ROLE OF SOCIAL ADVERTISING IN THE SOCIAL PROBLEMS REGULATION
}

\author{
Nataliya Oliyarnik ${ }^{1}$, Larysa Klymanska ${ }^{2}$ \\ Lviv Polytechnic National University, Lviv, Ukraine \\ ${ }^{1}$ Student, Department of Sociology and Social Work \\ ${ }^{2}$ Doctor of Political Science, Professor, Department of Sociology and Social Work
}

Background: The article deals with the interpretation of the concept of "social advertising". The state of the modern development of social advertising, which reflects the level of the Ukrainian society itself, its attitude to the problems that need urgent solution at the present stage of existence is analyzed, in order to prevent their further aggravation. The main problems of development of the sphere of social advertising in Ukraine are presented.

The purpose of this article is to study and to evaluate in details the state of social advertising, to demonstrate the social relevance and impact of advertising on social issues.

Methods: Theoretical research methods were used to analyze in details the state of social advertising and to summarize its role in solving social problems.

Results: The results of a theoretical analysis of scientific research have revealed the state of social advertising in Ukraine and the attitude of consumers to social advertising. The problems faced by social advertising in Ukraine are identified and solutions are suggested.

Conclusion: Social advertising as a complex activity is aimed at overcoming the negative trends that affect society. It occupies a specific place in the general classification of the genre of advertising, acquires specific features, and becomes an integral part of public life. However, in the present circumstances in our country, the activity of social advertising is insufficient. The state of Ukrainian social advertising demonstrates the urgent need to increase attention to social advertising. After all, social advertising is a type of communication that is constantly evolving, fulfilling its mission - to make the world a better place.

Keywords: social advertising, social problems, impact, prevention of social problems, Ukrainian society.

У регулюванні соціальних проблем важлива роль відводиться рекламі, а саме соціальній, мета якої, популяризація, прищеплення певних цінностей, ідеалів, стилю життя та поведінки. Соціальна реклама приходить у свідомість людини через ії звички, це вид навіювання зсередини. У результаті людина приймає нові критерії у своїх судженнях і виборі, засвоює їх спонтанно, думаючи, що сама ïx і обрала. Так соціальна реклама проводить поступову адаптацію людей до певного погляду на людські відносини. Усе це непомітно формує людину і змушує іiі відповідати стандартам суспільства. Така реклама направлена на створення і закріплення у свідомості людей норм і правил поведінки, відтворення та вдосконалення життєвих сил людини i соціуму, формування гармонійного соціального простору. Це серйозний механізм профілактики соціальних проблем, важливий інструмент створення соціальних цінностей.

Соціальна реклама несе в собі інформацію, представлену устислій, художній, емоційній формі. Вона допомагає людям краще упізнати проблему, привертає їхню увагу до найбільш важливих фактів, існуючих проблем і шляхів їх вирішення. Можливості такої реклами потужні за умови використання фахових підходів. Серед дослідників не існує єдиної думки щодо визначення поняття «соціальна реклама». Так, наприклад, харківська соціологиня Лисиця Н. М. розглядає це поняття як «неперсоніфікований спосіб передачі соціальної інформації від індивідуального або корпоративного актора до масового споживача, який може бути як комунікацією, так і спілкуванням та виключає акт купівлі або продажу» (Лисиця, 1999; с.37).

Актуальним у дослідженні соціальної реклами $є$ вивчення іiі як інструмента залучення суспільства в соціальні процеси, в більшості - формування здорового способу життя українського населення, і в першу чергу - молоді як економічного і соціального потенціалу майбутнього країни. Оскільки, саме «молодь особливо легко потрапляє під вплив засобів реклами, гуманізація освітньої парадигми ставить на чергу дня питання про необхідність поширення соціального рекламування бажаної системи цінностей та просоціальних моделей поведінки» (Тимошенко, 
Стрелковська, 2006), а призначення соціальної реклами - гуманізація суспільства і формування цінностей, що не викликає сумнівів в актуальності цієї проблематики.

Отже, соціальна реклама це вид рекламної комунікації, орієнтованої на привернення уваги населення країни до життєво важливих проблем суспільства і його соціальних пріоритетів.

Сьогодні реклама - це невід'ємна частина культури сучасного суспільства, яка пронизує всі сфери життя. В Україні така реклама існує вже понад двадцять років. В українському інформаційному просторі соціальна реклама займає важливе місце, розвиваючись як окремий напрям рекламної діяльності. На жаль, сьогодні соціальна реклама зіштовхується з низкою проблем:недосконалістю нормативно-законодавчої бази щодо замовлення, розповсюдження і виготовлення рекламної продукції; відсутністю об'єктивних оцінок ефективності соціальної реклами; неврахуванням або недостатнім урахуванням етичних і моральних аспектів змісту та законодавчої форми соціальної реклами (Україна. Закон “Про рекламу”).

Також, в Україні недостатнє фінансування такого виду реклами, «третина соціальної реклами $\epsilon$ саме комерційною прихованою рекламою» (Чала, 2013), про комерційний характер якої люди навіть не здогадуються, коли бачать іï на екранах чи біл-бордах. Ці факти характеризують ситуацію 3 негативної сторони і свідчать, що настав час рішучих дій, потреби посилення уваги до соціальної реклами, іiї недорозвиненості на теренах українського медіа простору.

Розвиток комунікативних технологій у всіх областях багатогранного життя сучасного суспільства приводить до нових форм споживання, не тільки виключно матеріальних продуктів, але й нових видів споживання інформації. В більшості, це пояснюється теоріями і концепціями інформаційного суспільства, в якому інформація стає якісно новим ресурсом, який є основною функціонування сучасного соціуму. Актуальність витоків інформації, яка являється основою будьякої комунікації, в тому числі - i соціальної реклами, не підлягає сумнівів сучасних фундаментальних наук. Як вказувалось, останнім часом соціальна реклама стає все більш популярною і в Україні, пропагуючи не тільки політичний настрій, але й мораль сім'ї, людських відносин, основи безпеки життєдіяльності і здоровий спосіб життя нового покоління.

Соціальна реклама стає сферою дослідження в теорії психології, соціології, політології, культурології. В цьому напрямку відбуваються конкурси, фестивалі, конференції і семінари, проходить обмін досвідом із закордонними партнерами. Проте, практика соціальної реклами продовжує залишатися доволі таки слаборозвинутою і мало представленою в сфері рекламної комунікації в Україні.

Населення України має досить низький «рекламноосвітній» рівень. Це було підтверджено нашим навчальним дослідженням, яке було проведене у листопаді 2019 року під загальною назвою «Роль соціальної реклами у регулюванні соціальних проблем». Впродовж цього дослідження нами було проведено декілька глибинних інтерв'ю. За мету такого дослідження було означено з'ясувати, як розуміють та оцінюють поняття «соціальна реклама» молоді люди; визначити міру сприйняття реклами у регулюванні соціальної проблем алкоголізму; визначити вплив «соціальної реклами» у врегулюванні проблеми алкоголізму. В даному дослідження застосовувалась так звана теоретична вибірка, тобто відбір випадків (чи індивідів) на основі їx характеристик, що відображають певний аспект теорії, яка розробляється. Для аналізу відібрано 3 вікові категорії: 20-25 років; 25-30 років; 30-35 років 3 метою визначення відмінностей впливу соціальної реклами на молодь.

Проведений аналіз текстів поглиблених інтерв'ю засвідчив, що опитані інформанти не зовсім чітко розуміють саме явище «соціальна реклама». До прикладу, після демонстрації рекламного відеоролику пива бренду «Чернігівське: Вживай відповідально» майже всі вони стверджували, що цей ролик можна вважати соціальною рекламою: «...оией мені дуже сподобався, ией ролик,... Це такі реклами, які запам'ятовуються, тобто, навіть запам'ятовуються людям, навіть на слух і на бачення, і там такі фрази є, і просто для мене ие ідеальний ролик, про алкоголізм коли за кермом, щзоб не сідати, цее просто дуже-е-е крутезний соціальний ролик»; “...якби не власне ия фірма, то таку рекламу б не крутили по нашому телебаченню, i власне тому вона для нас виглядає соиіальною, бо іншого варіанту вибору в нас на телебаченні немає. Ну-у я думаю, якби я не знала, щзо це за фірма, то я б була 
впевнена, що ие соціальна реклама...»; «... більще рекламують товар ніж говорять про саму проблему...».

Практично всі інформанти звертали увагу на те, що соціальної реклами мало, і ії дуже важко згадати: «..не видно сочіальної реклами. В нас такої аж великої соціальної реклами немає. Ну іï дуже мало. Навіть можна сказати мізерна, мізерна, мізерна, частинка. (сміється)»; «мені здається цієї реклами комплексно має бути багато тому, щуо порівняно з тим, що зараз в нас є на телебаченні то ї̈ ... мінімум, мінімум. Мені здається, щзо ї̈ треба розкручувати $i$ розвивати різносторонньо: може бути декілька підходів в одній рекламі для того, щуоб вона мала такий більш глобальний комплексний характер»; "От чесно мені бракує такої реклами. Є суто реклама товару, «такий класний товар», «чому той товар виник?», а щэо робити щэоб не було тої проблеми? Якось більще треба в це заглиблюватись».

Соціальна реклама для респондентів - це та ж реклама, і вона точно так само «продає», певні товари. Очевидно, що, на відміну від комерційної реклами, вона не приносить належного прибутку, тому не є такою ж популярною, як комерційна чи політична (у передвиборний період). Комерційна реклама пов'язана з конкретними продуктами, брендами. Для того, щоб точніше визначити соціальну рекламу і відокремити іiї від інших видів реклами, український медіа простір потребує саме якісної соціальної реклами. Продемонстроване ставлення споживачів до соціальної реклами може призвести до підриву довіри суспільства до такого виду реклами. Саме соціальна реклама потребує максимально креативного підходу під час створення, значних зусиль і розуміння висвітлюваної теми, а саме: використання даних 3 соціологічних досліджень (що важливо на початку запуску рекламної кампанії; чіткого відмежування соціальної реклами від політичної, комерційної; реагування соціальної реклами на болючі проблеми суспільства; використання історичної тематики для максимального наближення рекламних текстів до споживачів рекламної продукції; введення процедури ліцензування соціальної реклами з метою покращення якості і посилення довіри до неї.

Сучасне суспільство усіма силами намагається боротися 3 різними видами соціальних проблем, приймаючи закони, які передбачають арешт і тюремне ув'язнення порушників громадського порядку. У вирішенні соціальних проблем важливу роль повинно відводитись саме рекламі, адже, дуже важливо попереджати проблему, використовувати рекламу як профілактичний засіб для будь-якої соціальної хвороби. Стан сучасного розвитку соціальної реклами віддзеркалює рівень самого українського соціуму і його ставлення до проблем, що потребують термінового вирішення на сучасному етапі існування. Натомість соціальну рекламу не використовують, а навіть якщо і так, то рівень їі поширення не можна назвати масовим, а отже не ефективним.

\section{References:}

Lisitsa, N. (1999) Advertising in Modern Society: Kharkiv: The Basis - 272 p.

Tymoshenko (Strelkovskaya), A. (2006). Social Advertising in Ukraine: An Analysis of the Impact on the Formation of Positively Targeted Youth Behavior. Ukrainian society. Scientific journal. №2. 69-77.

Ukraine. Law on Advertising No. 1121-IV. (2004). URL: http: //zakon4.rada.gov.ua/laws/show/270/96$\% \mathrm{D} 0 \% \mathrm{~B} 2 \% \mathrm{D} 1 \% 80$. (Accessed 07/04/20.)

Chala, Y. (2013) Social advertising as a kind of conscious influence on society. Bulletin of Sumy National Agrarian University. Finance and Credit. - No. 1. 173-184. Retrieved from URL: http: //nbuv.gov.ua/UJRN/Vsnau_2013_1_33. (Accessed 09/04/20)

\section{Список використаної літератури:}

Лисица, Н. (1999) Реклама в современном обществе: Харків: Основа - 272 с.

Тимошенко (Стрелковська), А. (2006). Соціальна реклама в Україні: аналіз впливу на формування позитивно спрямованої поведінки молоді. Украӥнський сочіум. №2 . 69-77.

Закон України “Про рекламу” № 1121-IV. (2004). URL:http://zakon4.rada.gov.ua/laws/show/270/96\%D0\%B2\%D1\%80. (Дата звернення:07.04.20.) 
Чала, Ю.(2013) Соціальна реклама як різновид усвідомленого впливу на соціум. Вісник Сумського національного аграрного університету. Фінанси і кредит. - № 1. 173-184. Отримано з URL:http://nbuv.gov.ua/UJRN/Vsnau_2013_1_33. (Дата звернення: 09.04.20.)

\section{Contact information:}

Nataliya Oliyarnik

nataliaoliarnik16@gmail.com

Klymanska Larysa

Larysa_kl@ukr.net 